\title{
Giant marine viruses?
}

\author{
Gunnar Bratbak ${ }^{1}$, Ole Henrik Haslund ${ }^{2}$, Mikal Heldal ${ }^{1}$, Anne Næss ${ }^{1}$, Torill Røeggen ${ }^{1}$ \\ ${ }^{1}$ Department of Microbiology and Plant Physiology, University of Bergen, Jahnebakken 5, N-5007 Bergen, Norway \\ ${ }^{2}$ Department of Microbiology, Water Quality Institute, DK-2970 Hørsholm, Denmark
}

ABSTRACT: Unusually large virus-like particles (VLPs) with tails were found in water samples from Norwegian and Danish coastal waters. Size of the VLP heads were 340 to $400 \mathrm{~nm}$ and the tails were 2.2 to $2.8 \mu \mathrm{m}$ long. The VLPs occurred at a maximum concentration of about $10^{4} \mathrm{ml}^{-1}$. The possible hosts are unknown

Most viruses measure between 20 and $350 \mathrm{~nm}$ (Bitton 1980). The largest are found among the animal viruses and the smallest among the plant viruses and the bacteriophages. Filamentous viruses may be as long as $1000 \mathrm{~nm}$ or longer, but the diameter of these viruses is $10 \mathrm{~nm}$ or less (Bradley 1967, Laskin \& Lechevalier 1973). The viral population of natural marine waters is dominated by forms with heads $<60 \mathrm{~nm}$ in diameter (Bergh et al. 1989). Most of these small viruses are thought to be bacteriophages (Bratbak et al 1990). Viruses in the size range of 100 to $150 \mathrm{~nm}$ usually make up $<1$ to $10 \%$ of marine viral communities.

Water samples in which we observed unusually large virus-like particles (VLPs) were collected at $0.2 \mathrm{~m}$ depth in Raunefjorden, western Norway in April 1991 (Bratbak et al. 1990) and during a mesocosm experiment in Knebelvig, Denmark in July 1991 (Nybroe et al. 1992). The mesocosm experiment was set up in the beginning of July and sampled every 2 or $3 \mathrm{~d}$ for $3 \mathrm{wk}$. Samples preserved with $1 \%$ glutaraldehyde were harvested by centrifugation onto electron microscope grids, stained with $2 \%$ uranyl-acetate, and inspected in a JEOL100CX transmission electron microscope as previously described (Børsheim et al. 1990, Bratbak et al. 1990).

The VLPs (Fig. 1a) we observed in the mesocosm experiment were found in 2 of the 4 enclosures investigated. A maximum concentration of $\mathrm{ca} 10^{4} \mathrm{ml}^{-1}$ was observed on Day 5 of the experiment. The particles were also found in the sample taken 3 d later, but not in earlier or later samples. The head structure of the particles appears to have an octahedral form and the size of the head, as it appears on the electron micro- graphs, was $370 \mathrm{~nm}(\mathrm{SD}=17) \times 340 \mathrm{~nm}(\mathrm{SD}=12)$. The tail structure was ca $2.2 \mu \mathrm{m}(\mathrm{SD}=0.3)$ long and 80 to $85 \mathrm{~nm}$ wide. The VLP found in the free water masses of Raunefjorden was similar in morphology to the VLP found in the enclosure study (Fig. $1 \mathrm{~A}, \mathrm{~B}$ ) but the head structure was slightly larger $(400 \times 370 \mathrm{~nm})$ and the tail structure was about $2.8 \mu \mathrm{m}$ long and 55 to $60 \mathrm{~nm}$ wide. The only comparable VLP we know of has a head diameter of $390 \mathrm{~nm}$ and a tail of about $1 \mu \mathrm{m}$ and has been found in cultures of the filamentous green algae Uronema gigas (Dodds \& Cole 1980).
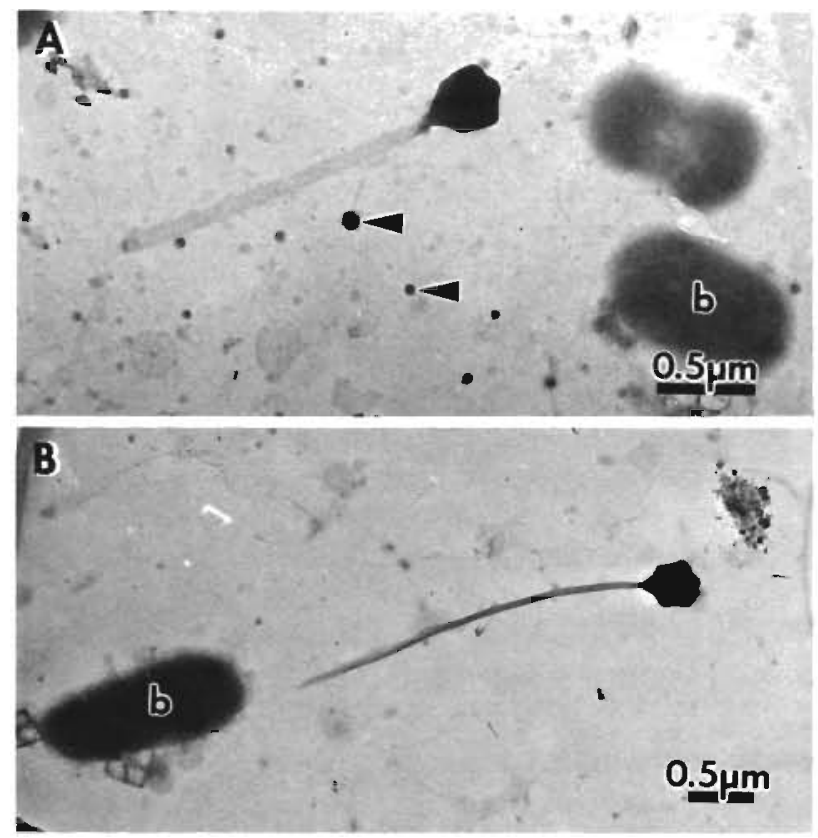

Fig. 1. Transmission electron micrograph of the unusually large virus-like particles. (A) Sample from mesocosm experiment in Denmark; (B) sample from Raunefjorden, Norway. Arrow: virus-like particles of a more typical size $(<100 \mathrm{~nm})$; b: bacterium 
Compared to microorganisms such as bacteria and flagellates, viruses will generally appear as electrondense structures after positive staining with uranylacetate due to their high nucleic acid content. As shown in Fig. 1A, B the large VLPs have a high electron density in the head structure. We do not know of any biological or non-biological structure that gives a similar appearance after this preparation and we therefore assume that these particles are indeed viruses.

The host of the viruses found in the enclosure study must be a planktonic organism because they were produced within the enclosures where only planktonic organisms were present. The size of these large viruses limits the number of possible host organisms. The viruses we observed resemble tailed bacteriophages but the size of the bacteria (Fig. 1) found together with the viruses makes them unlikely hosts. The eucaryotic community found together with the virus in the enclosure study was numerically dominated by unidentified autotrophic and heterotrophic forms that were 1 to $5 \mu \mathrm{m}$ in diameter. The most abundant larger phytoplankton forms included the diatoms Rhizosolenia fragilissima and Probiscia alata; some unidentified cryptophyceans; some dinophyceans (including Gymnodinium sp. and Scripsiella sp.); and the chrysophyceans Dinobryon balticum and $D$. petriolatum. The most abundant protozoans included colorless flagellates, and the ciliates Urotricha sp., Strombidium spp., and Mesodinium rubrum.

The roles of viruses in natural waters have just begun to be revealed and we are still groping to find our way with new methods and approaches. Our observation of the large VLP is mainly qualitative and its host is unknown. The finding does emphasize that the choice of method for detecting and counting viruses may be crucial. Large viruses such as those described here would probably have been lost if any prefiltration had been applied (Cottrell \& Suttle 1991, Paul et al. 1991) and they would probably have been considered small bacteria if they had been observed in the epifluorescence microscope after staining with DAPI (Hara et al. 1991).

This note was submitted to the editor
Acknowledgements. This study was supported by the EEC MAST program, contract no. 0020, the Danish Natural Research Council, Danish Technical Research Council (J.-nos. 11-8630 and 16-4806). National Agency of Environmental Protection in Denmark (HAV9o - Marine Research Programme in Denmark - contract no. 1.23), the Royal Norwegian Council for Scientific and Industrial Research (contract 27744), the Norwegian Council for Fisheries Research, and the Norwegian Council for Science and the Humanities. The electron microscope work was done at the Laboratory for Electron Microscopy, Science Faculty, Univ. of Bergen.

\section{LITERATURE CITED}

Bergh, Ø., Børsheim, K. Y., Bratbak, G., Heldal, M. (1989). High abundance of viruses found in aquatic environments. Nature, Lond. 340: $467-468$

Bitton, G. (1980). Introduction to environmental virology. John Wiley \& Sons, New York

Bradley, D. E. (1967). Ultrastructure of bacteriophages and bacteriocinds. Bact. Rev. 31: 320-314

Bratbak, G., Heldal, M., Norland, S., Thingstad, T. F. (1990). Viruses as partners in spring bloom microbial trophodynamics. Appl. environ. Microbiol. 56: 1400-1405

Børsheim, Y., Bratbak, G., Heldal, H. (1990). Enumeration and biomass estimation of planktonic bacteria and viruses by transmission electron microscopy. Appl. environ. Microbiol. 56: 352-366

Cottrell, M., Suttle, C. (1991). Wide-spread occurrence and clonal variation in viruses which cause lysis of a cosmopoli$\tan$, eucaryotic marine phytoplankter Micromonas pusilla. Mar. Ecol. Prog. Ser. 78: 1-9

Dodds, J. A., Cole, A. (1980). Microscopy and biology of Uronema gigas, a filamentous eucaryotic green algae, and its associated tailed virus-like particle. Virology 100: $156-165$

Hara, S., Terauchi, K., Koike, I. (1991). Abundance of viruses in marine waters: assessment by epifluorescence and transmission electron microscopy. Appl. environ. Microbiol. 57 : 2731-2734

Laskin, A. I., Lechevalier, H. A. (1973). Handbook of microbiology, Vol. I. Organismic microbiology. CRC Press, Cleveland, Ohio

Nybroe, O., Christoffersen, K., Riemann, B. (1992). Survival of Bacillus licheniformis in seawater model ecosystems. Appl. environ. Microbiol. 58: 252-259

Paul, J., Jiang S. C., Rose J. B. (1991). Concentration of viruses and dissolved DNA from aquatic environments by vortex flow filtration. Appl. environ. Microbiol. 57: 2197-2204

Manuscript first received: March 26, 1992

Revised version accepted: July 8, 1992 